\title{
RADIOACTIVITY LEVELS AND DOSE RATES FROM ROCKS IN SELECTED MINING AREAS AND QUARRIES IN EASTERN UGANDA
}

\author{
A.Mugaiga $^{1 *}$, E.Jurua $^{2}$, R.Oriada $^{3}$, S.Turyahabwa $^{4}$ \\ ${ }^{1,2,3,4}$ Department of Physics Kyambogo University, Kampala Uganda. \\ ${ }^{2}$ Department of Physics Mbarara University of Science and Technology, Uganda. \\ *Author of Correspondence: Mugaiga Aron, mugaigaaron@gmail.com
}

\begin{abstract}
The aim of this study was to determine the radioactivity levels and dose rates due to natural radionuclides in rocks from selected mining areas and quarries in Eastern Uganda. 60 rock samples collected from six mines and quarries were analyzed using a NaI gamma detector. The specific activities of ${ }^{238} U,{ }^{232} \mathrm{Th}$ and ${ }^{40} \mathrm{~K}$ in the samples were measured, the gamma dose rate and annual effective dose outdoor were determined. The specific activities ranged from $13.95 \pm 0.31$ to $698.02 \pm 3.38 \mathrm{~Bq} \mathrm{~kg}^{-1}$ for ${ }^{238} \mathrm{U}$, $98.68 \pm 1.30$ to $2397.78 \pm 19.64 \mathrm{~Bq} \mathrm{~kg}^{-1}$ for ${ }^{232} \mathrm{Th}$, and $45.97 \pm 2.48$ to $2183.80 \pm 17.89 \mathrm{~Bq} \mathrm{~kg}^{-1}$ for $^{40} \mathrm{~K}$. The absorbed dose rates were calculated and the values obtained at all sites are above the world average of $59 n G y h^{-1}$. The annual effective dose rate outdoor for all the sites ranges from 0.30 to $1.37 \mathrm{mSv} y^{-1}$. The average annual effective dose rate outdoor for some areas are below 1.00 $m S v y^{-1}$, the lowest permissible limit set by the International Commission on Radiation Protection (ICRP); while other sites have the annual effective dose rates higher than unity which suggests a health risk to the inhabitants of the areas. Therefore, the National Environmental Management Authority (NEMA) should monitor the disposal of radioactive wastes from the mines in this region for human safety.
\end{abstract}

Keywords: Gamma Radiation, Radioactivity Levels, Absorbed Dose Rate, Mining, Rocks, Quarries.

\section{INTRODUCTION}

All living creatures are faced with unceasing exposure to ionizing radiation. Organisms are majorly faced with exposure to radiation from terrestrial sources and cosmic rays [24]. Radionuclides that naturally exist in the terrestrial environment of rocks, soils and vegetation are the major sources of irradiation to the organisms or human beings [15]. These natural radionuclides include; ${ }^{40} \mathrm{~K},{ }^{238} \mathrm{U}$ and ${ }^{232}$ Th series, and their decay products among others.

All types of rocks contain natural radioactive compounds in varying quantities. Higher radiation levels are associated with igneous rocks, such as granite, while lower levels are associated with sedimentary rocks. Shales and phosphate rocks also have relatively high content of radionuclides [21]. Natural radioactive compounds contained in rocks emit alpha, beta and gamma radiation. Most of this radiation gets absorbed by the rocks themselves and never make it into the air. Gamma radiation has a strong penetrating power and can pass through the rocks and get into the air. This is therefore the type of radiation that organisms are always exposed to.

Natural gamma radiation levels in rocks are of great interest because rocks are ores for mining and processing; and they are used as raw materials in industries (e.g. Cement industry and Steel industry) to make materials such as cement and limestone used as building and ornamental materials. Mining operations and other industrial activities involving rocks as raw materials expose radioactive materials in the mining waste. This makes it more accessible to human contact. More exposure to radioactive materials alters/increases the background radiation levels exposed to man from terrestrial sources [21].

Gamma radiations have sufficient energy to remove electrons from their atomic or molecular orbital shells in the tissues they penetrate. These radiations, if received in sufficient quantities over a period of time, can result in tissue damage and disruption of cellular function at molecular level [22]. Higher radiation doses and higher dose rates can impair the functioning of tissues or organs and produce acute effects such as skin redness, hair loss, birth defects, illness, cancer, and death [23].

Previous studies (e.g [25], [3], [8]) have shown that significant amount of radiation from terrestrial sources originate from rocks. Furthermore, radiation from terrestrial sources is increased by human activities such as mining [21].

Gamma-ray spectrometric analysis of sediment rocks along the shores of Lake Nakuru, a site in Kenya, show that the average activity concentrations for ${ }^{238} \mathrm{U},{ }^{232} \mathrm{Th}$ and ${ }^{40} \mathrm{~K}$ are 36.9 $\pm 9.1 \mathrm{~Bq} \mathrm{~kg}^{-1}, 43.5 \pm 3.8 \mathrm{~Bq} \mathrm{~kg}^{-1}$ and $708.3 \pm 33.2 \mathrm{~Bq} \mathrm{~kg}^{-1}$ respectively and the average absorbed dose rate was found to be $0.088 \pm 0.007 \mathrm{mSv} \mathrm{y}^{-1}$. This value is less than the safety limit to public exposure of $1 \mathrm{mSvy}^{-1}$ [25]. The hazard index was found to be $0.410 \pm 0.034$ which is less than the safety limit of 1 . The activity concentration of Uranium and Potassium were higher than the world average which suggests a health hazard to the public. 
The results of a study carried out on natural radioactivity at Minjingu phosphate rocks in Tanzania showed that there was high concentration of radium-226 of $5760 \pm 107 \mathrm{~Bq} \mathrm{~kg}^{-1}$ in phosphate rock, $4250 \pm 98 \mathrm{~Bq} \mathrm{~kg}^{-1}$ in waste rock, $650 \pm$ $11 \mathrm{~Bq} \mathrm{~kg}^{-1}$ in wild leaf vegetation, $393 \pm 9 \mathrm{~Bq} \mathrm{~kg}^{-1}$ in edible leaf vegetation and $4.0 \pm 0.1 \mathrm{~Bq} \mathrm{~kg}^{-1}$ in chicken feed. This suggests a radiation health risk particularly when the samples are ingested [3]. The radiation dose from ambient air over five years at this phosphate mine averaged 1415 $\mathrm{nGy} \mathrm{h}^{-1}$. This implies that the workers in the mines and those who live around the mines are at a very big risk of suffering radiation effects such as cancer, if control measures are not sought. It also showed that high radiation levels in rocks affect the crops grown around this area.

In a study on natural radioactivity in soil and phosphate samples from El-Sabaea, Aswan in Egypt found out that the concentration of ${ }^{226} \mathrm{Ra},{ }^{232} \mathrm{Th}$ and ${ }^{40} \mathrm{~K}$ ranged from $59.7 \pm 6.7$ to $638 \pm 31.0,9.9 \pm 1.4$ to $40.6 \pm 6.3$ and $213.1 \pm 9.5$ to $798.9 \pm 30.6$ in $\mathrm{Bq} \mathrm{kg}^{-1}$ respectively [8]. The study showed that phosphate rocks contain relatively high concentration of naturally occurring radioactive materials from Uranium and Thorium decay series. The study indicates that rocks in such sites are not safe to be used as building materials.

A study on low level radionuclide counting of Cs, U, Th and $\mathrm{K}$ in selected Ugandan foods and their corresponding soils of growth in Mbale district in Uganda revealed high activity levels due to $\mathrm{Th}$ and $\mathrm{K}$. These ranged from $644 \mathrm{~Bq} \mathrm{~kg}^{-1}$ to $674 \mathrm{~Bq} \mathrm{~kg}^{-1}$. The average activity concentration of Uranium was $20 \mathrm{~Bq} \mathrm{~kg}^{-1}$ [13]. These high values of activity concentrations of $\mathrm{Th}, \mathrm{U}$ and $\mathrm{K}$ in foods originate from the high concentration of radionuclides in the soils, where the crops are grown and the rocks around them. The study, however, did not cater for the activity concentration of radionuclides in rocks and gamma radiation exposure to the inhabitants.

Unfortunately, not much work seems to have been done to study the radiation levels of rocks in mining areas and non mining areas in Uganda. Yet mining has been going on in the country for decades and rocks generally have a high demand. They are used as hardcore in construction of houses and are also used in industries to produce building materials such as cement, limestone, slate, bricks etc that are used countrywide.

Eastern Uganda particularly has a considerable number of mining areas and industries. Some of the mining areas and quarries in Eastern Uganda include Osukuru hills and Tororo rock mines in Tororo district, Kaseremu mines in Kapchorwa district, Nandotome quarries in Mbale district etc. Since human activities such as mining can alter/increase the background radiation levels from terrestrial sources [21], this may increase absorbed dose rate received from natural sources by individuals who work in the mines and the inhabitants of the area [19]. This study therefore, focused on determining the radioactivity levels as well as the dose rates from rocks in the mines and quarries in this region. The samples studied were collected from the surface and prepared before they were taken to the laboratory for counting. This is discussed in the following section.

\section{MATERIALS AND METHODS}

\subsection{Sample Collection and Preparation}

Six sites from Eastern Uganda were considered in this study i.e. Osukuru hills and Tororo rock mines in Tororo district, Nabumali quarry mines in Mbale district, Bubenzi and Nkota mines in Bukhulo Sironko district, and Kaseremu mines in Kapchorwa district.

In collecting the rock samples, no particular size was considered. The random sampling method recommended by the International Atomic Energy Agency [9] was followed in collecting the samples to ensure a good statistical representation of the sampling areas i.e. each sampling site was divided into three sections and from each section three or four samples were collected at an approximate distance of $30 \mathrm{~m}$ apart. Ten (10) rock samples were collected in poly ethene bags from the ground at each site giving a total of 60 samples.

The samples were oven dried to completely remove moisture so as to avoid clamping during crushing. They were then crushed using hummer to obtain fine particles that could easily be milled to fine powder in order to attain a uniform mixture and increase the surface area for interaction of the radionuclides with the detector. Milling was done using an electric ball mill. The pulverized samples were weighted using a beam balance and sealed in air tight standard $500 \mathrm{ml}$ plastic Marinelli beakers. The air tight sealed samples were stored for 21 days before counting in order to attain secular equilibrium between ${ }^{232} \mathrm{Th}$ series and ${ }^{238} \mathrm{U}$ series with their decay products [16].

\subsection{Measurement of Gamma Energy.}

The measurement of gamma energy was implemented using a NaI gamma detector. The gamma detector used was calibrated first. The calibration was performed using the peaks of Eu-152 whose activity is known. Eu-152 was placed on the NaI crystal and its spectrum obtained. The peaks of known energies were used to calibrate the gamma spectrometer. Principally the channel number is proportional to the gamma energy. The channel scale was then converted to an energy scale.

While there was no radiation source in the detector, a spectrum was generated that was used to determine the amount of background radiation. The background radiation obtained was later subtracted from the measurement for each sample to obtain actual radiation from radionuclides in the samples. Each sample was put in the gamma spectrometer, counting was done for a minimum of $6000 \mathrm{~s}$ in order to generate a clear spectrum for analysis. To further reduce the interference from background radiation, Lead absorbers were used to shield the detector against radiations from the background [7]. 
The gamma spectrum generated for each sample had energy peaks corresponding to the radionuclides present in the sample. Every observed energy peak on the gamma spectrum was compared with the standard energy peaks of the various radionuclides in nature and the radionuclides present in each sample were identified.

\section{RESULTS AND DISCUSSION}

The radionuclides identified in the samples are shown in the Table 1.

Table 1: The radionuclides identified and their emitter nuclides

\begin{tabular}{|c|c|c|c|}
\hline $\begin{array}{c}\text { Experimental } \\
\text { Gamma ray } \\
\text { energy (keV) }\end{array}$ & $\begin{array}{c}\text { Standard } \\
\text { Gamma } \\
\text { ray } \\
\text { energy } \\
\text { (keV) }\end{array}$ & $\begin{array}{c}\text { Emitter } \\
\text { nuclide }\end{array}$ & Radionuclide \\
\cline { 1 - 3 } $202.74 \pm 13.25$ & 238 & ${ }^{212} \mathrm{~Pb}$ & \multirow{2}{*}{${ }^{232} \mathrm{Th}$} \\
\hline $533.18 \pm 20.44$ & 580 & ${ }^{208} \mathrm{Tl}$ & \\
\hline $844.68 \pm 33.89$ & 860.51 & ${ }^{208} \mathrm{Tl}$ & \\
\hline $259.82 \pm 12.47$ & 295 & ${ }^{214} \mathrm{~Pb}$ & \multirow{2}{*}{${ }^{238} \mathrm{U}$} \\
\hline $306.82 \pm 13.84$ & 351.92 & ${ }^{214} \mathrm{~Pb}$ & \\
\hline $1311.49 \pm 31.17$ & 1460.81 & \multicolumn{2}{|c|}{} \\
\hline
\end{tabular}

Uranium, Thorium and Potassium as shown in Table 2 were found present in significant levels in all the samples studied. Other natural radionuclides appeared at trace levels in all the samples studied.

The presence of Uranium, Thorium and Potassium in rocks was expected since these radionuclides occur in nature in almost all rock types but with varying elemental concentrations. This study revealed an enhanced elemental concentration of Uranium (U) and Thorium (Th) in the rocks from mines and quarries in Eastern Uganda. Enhanced elemental concentration of Uranium (U) and Thorium (Th) is associated with Granitic rocks as compared to the very low levels of these elements exhibited by the mantle and the crust of the Earth [5].

The gamma-ray energies obtained on the spectrum generated were used to calculate the specific activities of ${ }^{238} \mathrm{U},{ }^{232} \mathrm{Th}$ and ${ }^{40} \mathrm{~K}$ using Equation (1).

\subsection{Specific Activities In Rock Samples}

The specific activity $A_{s}$ of detected radionuclides were calculated using the equation:

$$
A_{S}=\frac{N_{e}}{t \times m_{i} \times c_{i}}\left(\mathrm{~Bq} \mathrm{~kg}^{-1}\right) \text {, }
$$

where $N_{e}$ is the net Peak Area at energy $e, m_{i}$ the mass in $\mathrm{kg}$ of the measured sample $i, t$ the counting time and $C_{i}$ is given by; $c_{i}=\eta \times \rho$

where $\eta$ is the detector efficiency and $\rho$ the branching ratio.

The specific activity of ${ }^{232} \mathrm{Th}$ was determined from its decay products ${ }^{212} \mathrm{~Pb}(238 \mathrm{keV}),{ }^{208} \mathrm{Tl}(580)$ and ${ }^{208} \mathrm{Tl}(860.56$ $\mathrm{keV})$, while the specific activity of ${ }^{238} \mathrm{U}$ was determined from its decay products ${ }^{214} \mathrm{~Pb}(295 \mathrm{keV})$ and ${ }^{214} \mathrm{~Pb}(351.92$ $\mathrm{keV})$. The specific activity of ${ }^{40} \mathrm{~K}$ was determined from its $1460 \mathrm{keV}$ gamma spectrum. More details of the spectroscopic results are shown in Table 1.

The average specific activities obtained are presented in Table 2 and graphically illustrated in Figure 1.

Table 2: The mean specific activities of ${ }^{238} \mathrm{U},{ }^{232} \mathrm{Th}$ and ${ }^{40} \mathrm{~K}$ in rocks from all sites.

\begin{tabular}{|l|c|c|c|}
\hline \multirow{2}{*}{ SITE NAME } & \multicolumn{3}{|c|}{ MEAN SPECIFIC ACTIVITIES } \\
& ${ }^{\left(\mathrm{Bq} \mathrm{kg}^{-1}\right)}$ & \\
\hline & $\mathbf{U}$ & ${ }^{232} \mathbf{T h}$ & ${ }^{\mathbf{2 0}} \mathbf{K}$ \\
\hline $\begin{array}{l}\text { KASEREMU } \\
\text { MINES }\end{array}$ & $16.8 \pm 0.6$ & $541.3 \pm 31.5$ & $936.4 \pm 34.7$ \\
\hline $\begin{array}{l}\text { OSUKURU } \\
\text { HILLS }\end{array}$ & $171.5 \pm 12.3$ & $804.5 \pm 288.4$ & $192.7 \pm 45.2$ \\
\hline $\begin{array}{l}\text { TORORO } \\
\text { ROCK }\end{array}$ & $112.6 \pm 4.5$ & $1753.9 \pm 57.3$ & $132.2 \pm 22.7$ \\
\hline $\begin{array}{l}\text { BUBENZI } \\
\text { QUARRIES }\end{array}$ & $60.7 \pm 7.0$ & $244.9 \pm 22.9$ & $1587.3 \pm 91.7$ \\
\hline $\begin{array}{l}\text { NKOTA } \\
\text { QUARRIES }\end{array}$ & $24.0 \pm 2.1$ & $1169.5 \pm 110.9$ & $1856.5 \pm 63.9$ \\
\hline $\begin{array}{l}\text { NATONDOME } \\
\text { QUARRIES }\end{array}$ & $51.3 \pm 4.0$ & $1291.9 \pm 94.5$ & $1816.9 \pm 55.8$ \\
\hline
\end{tabular}

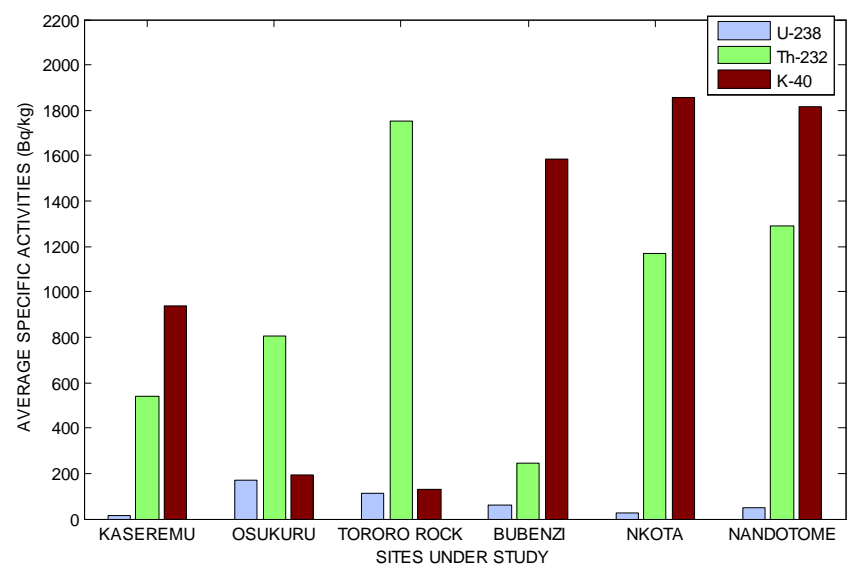

Figure 1: The mean specific activities of ${ }^{238} \mathrm{U},{ }^{232} \mathrm{Th}$ and ${ }^{40} \mathrm{~K}$ for rock samples from the sites under study

Samples from Osukuru hills and Tororo rock were found to possess high specific activities of Thorium and Uranium. Generally Tororo rock has the highest specific activity levels of Thorium and Osukuru hills have the highest specific activity levels of Uranium. 
The highest average specific activity of ${ }^{238} \mathrm{U}(171.5 \pm 12.3 \mathrm{~Bq}$ $\left.\mathrm{kg}^{-1}\right)$ observed at Osukuru hills and ${ }^{232} \mathrm{Th}(1959.1 \pm 16.4 \mathrm{~Bq}$ $\mathrm{kg}^{-1}$ ) observed at Tororo rock samples may be due to the presence of accessory minerals such as monazite, thorite, uranothorite and zircon [18]. Uranium and Thorium are generally enriched in the youngest and most potassic members of comagmatic suites of igneous rocks [18]. This suggests that higher values of ${ }^{238} \mathrm{U}$ and ${ }^{232} \mathrm{Th}$ could be due to the presence of higher amount of these accessory minerals.

Thorium was observed to have higher specific activities than Uranium in all the sites considered. This could be due to the natural abundance of thorium in the earth crust which is about four times the abundance of uranium [6]. Therefore the values of specific activities of Thorium are expected to be higher than those of Uranium in all Samples.

The highest average activity concentration of Uranium observed at Osukuru hills was 5 times higher than the world average. This explains why part of the area (Osukuru hills) was gazetted for the extraction of Uranium. The neighboring site of Tororo rock mines also had a very high specific activity of Uranium, which was 4 times higher when compared to the world average. The whole area (Osukuru hills) is a Uranium deposit since part of it $\left(26 \mathrm{~km}^{2}\right)$ has already been gazetted for the extraction of Uranium, base metals and Phosphates.

Potassium-40 $\left({ }^{40} \mathrm{~K}\right)$ has the highest specific activity levels at the sites of Nkota quarries, Nandotome quarries, Bubenzi quarries and Kaseremu mines. The highest specific activity of ${ }^{40} \mathrm{~K}\left(2183.8 \pm 46.7 \mathrm{~Bq} \mathrm{~kg}^{-1}\right)$ is observed at Nkota quarries. ${ }^{40} \mathrm{~K}$ occurs in major minerals such as feldspar and micas [17]. Potassium is widely spread in the environment with an average concentration of $1.7 \mathrm{~g} / \mathrm{kg}$ in plants and animals, 27 $\mathrm{g} / \mathrm{kg}$ in crustal rock and $380 \mathrm{~g} / \mathrm{L}$ in ocean waters [4]. Also potassium is naturally needed by almost all living things (animals and plants) for their growth and this is why it has to exist in abundance in nature. Potassium is also highly concentrated in granite rocks and these comprise of major deposits of Potassium salts.

The results obtained in this work are comparable with specific activities of radionuclides reported in some studies of high background radiation areas e.g. Kinyua et al [12] reported the mean specific activity of Potassium as 1780.0 $\mathrm{Bq} \mathrm{kg}{ }^{-1}$ for Orenge quarries, and $1020.0 \mathrm{~Bq} \mathrm{~kg}^{-1}$ for Nyaberi quarries in Kisi, Kenya. This compares with the average specific activity of Potassium obtained from Nandotome quarries $\left(1817.0 \pm 55.8 \mathrm{~Bq} \quad \mathrm{~kg}^{-1}\right), \quad$ Nkota quarries $\left(1856.51 \pm 63.89 \mathrm{~Bq} \mathrm{~kg}^{-1}\right)$ and Bubenzi quarries (1587.3 \pm 91.7 $\left.\mathrm{Bq} \mathrm{kg}^{-1}\right)$.

Also Langat [14] reported a very high activity concentration of Potassium for sediment rocks at the shores of Lake Nakuru with mean specific activity of $708.3 \pm 33.2 \mathrm{~Bq} \mathrm{~kg}^{-1}$. This compares with that obtained from Kaseremu mines $\left(936.4 \pm 64.8 \mathrm{~Bq} \mathrm{~kg}^{-1}\right)$ in Kapchorwa district.

\subsection{Gamma Dose Rate}

The obtained mean specific activities of the various radionuclides were used to determine the gamma dose rate, $D$ using equation (3); [21]

$D=0.462 A_{U}+0.604 A_{T h}+0.0417 A_{K} \mathrm{nGy} \mathrm{h}^{-1}$,

Where $A_{T h}, A_{U}$ and $A_{K}$ are the mean activity concentrations of ${ }^{232} \mathrm{Th},{ }^{238} \mathrm{U}$ and ${ }^{40} \mathrm{~K}$ respectively.

The coefficients of $A_{U}, A_{T h}$ and $A_{K}$ are conversion factors used to convert specific activities into absorbed dose. These conversion factors were determined by UNSCEAR in 1993 and are extensively used in related calculations in the UNSCEAR report [20], [21] and are recommended worldwide.

The mean absorbed dose rates for all the sites under study were calculated and the results are presented in Table 3.

Table 3: The mean absorbed dose rate for all sites under

\begin{tabular}{|c|c|}
\hline SITE NAME & $\begin{array}{l}\text { MEAN ABSORBED DOSE } \\
\text { RATE }\left(\mathbf{n G y ~ h}^{-1}\right) \pm \text { S.E }\end{array}$ \\
\hline $\begin{array}{l}\text { KASEREMU MINES, } \\
\text { Kapchorwa }\end{array}$ & $373.8 \pm 19.1$ \\
\hline $\begin{array}{l}\text { OSUKURU HILLS, } \\
\text { Tororo }\end{array}$ & $573.3 \pm 79.6$ \\
\hline $\begin{array}{l}\text { TORORO ROCK, } \\
\text { Tororo }\end{array}$ & $1116.8 \pm 35.5$ \\
\hline $\begin{array}{l}\text { BUBENZI } \\
\text { QUARRIES, Sironko }\end{array}$ & $242.2 \pm 19.7$ \\
\hline $\begin{array}{l}\text { NKOTA QUARRIES, } \\
\text { Sironko }\end{array}$ & $794.8 \pm 68.4$ \\
\hline $\begin{array}{l}\text { NATONDOME } \\
\text { QUARRIES, Mbale }\end{array}$ & $879.8 \pm 60.5$ \\
\hline
\end{tabular}

The results in Table 3 are graphically illustrated in Figure 2 below.

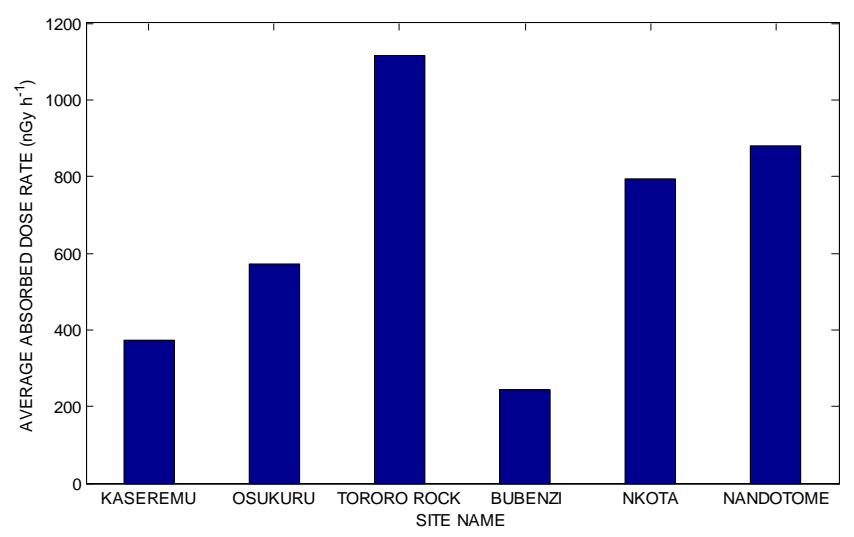

Figure 2: The absorbed dose rates for all sites under study 
From Figure 2, Tororo rock has the highest absorbed dose rate followed by Nandotome, while Bubenzi quarries has the lowest absorbed dose rate. The mean absorbed dose rate from Tororo rock mines is $1116.8 \mathrm{nGy} \mathrm{h}^{-1}$; and is about 19 times higher than the world average of $59 \mathrm{nGy} \mathrm{h}^{-1}$ as reported by UNSCEAR [21]. This could be due to the presence of very high activity per unit mass of ${ }^{232} \mathrm{Th}$, which contributes $95 \%$ to the total absorbed dose rate.

Generally the absorbed dose rates obtained in this work are higher than the world average but are within the range of those obtained from related studies for other places in the world e.g. Arafa [2], Achola [1] and Kinyua [12].

Tororo rock has interesting results; it has the highest absorbed dose rate compared to all the sites studied and other sites reported elsewhere. This high value is due to high levels of Thorium.

Figure 3 shows the percentage contribution of individual radionuclides to the total absorbed dose rate at Tororo rock.

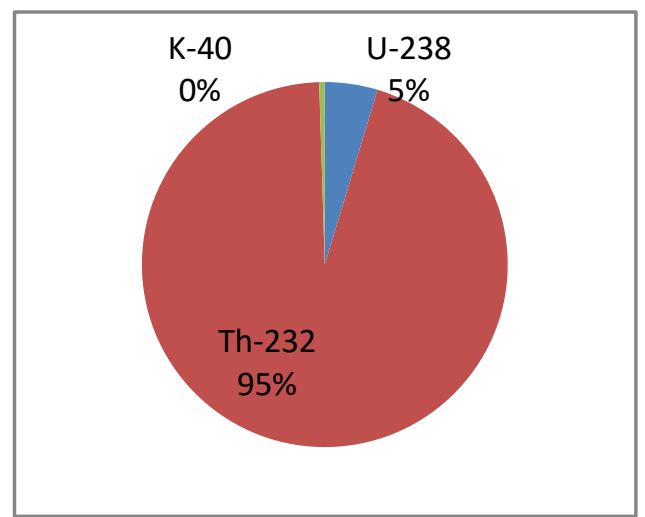

Figure 3: The percentage contribution of individual radionuclides to the total absorbed dose rate at Tororo rock

\subsection{Annual Effective Dose Rate- Outdoor}

\section{$\left(\mathrm{AEDR}_{\text {outdoor }}\right)$}

To estimate the $\mathrm{AEDR}_{\text {outdoor }}$, the conversion coefficient and the world average outdoor occupancy factor were used. In the UNSCEAR report [20], the Committee used 0.7 Sv Gy ${ }^{1}$ as the conversion coefficient (to convert absorbed dose rate in air to effective dose received by adults) and 0.8 as the indoor occupancy factor. Basing on the UNSCEAR report [21], on average around the world, people spend $20 \%$ of their time outdoors, this has been maintained in this work. The Annual effective dose rate outdoor, AEDR $_{\text {outdoor }}$ in units of $\mathrm{mSv} \mathrm{y}^{-1}$, was therefore calculated using the equation (4) [21];

$A E D R_{\text {outdoor }}=D \times P \times R \times Q \times 10^{-6}$,

where $D\left(\mathrm{nGy} \mathrm{h}^{-1}\right)$ is the absorbed dose rate, $P=8766 \mathrm{~h}$ i.e. the number of hours in a year, $R=0.2$ (outdoor occupancy factor) and $Q=0.7 \mathrm{~Sv} \mathrm{~Gy}^{-1}$ (the conversion coefficient).

The AEDR $_{\text {outdoor }}$ results obtained are presented in Table 4 and graphically illustrated in Figure 4.
Table 4: The annual effective dose- outdoor for all sites under study

\begin{tabular}{|c|c|c|}
\hline SITE NAME & $\begin{array}{c}\text { MEAN } \\
\text { ABSORBED } \\
\text { DOSE RATE } \\
\left(\mathrm{nGy} \mathrm{h}^{-1}\right)\end{array}$ & $\begin{array}{l}\text { ANNUAL } \\
\text { EFFECTIVE } \\
\text { DOSE- } \\
\text { OUTDOOR } \\
\left(\mathrm{mSv} \mathrm{y}^{-1}\right)\end{array}$ \\
\hline $\begin{array}{l}\text { KASEREMU } \\
\text { MINES }\end{array}$ & $373.8 \pm 19.1$ & 0.46 \\
\hline $\begin{array}{l}\text { OSUKURU } \\
\text { HILLS }\end{array}$ & $573.3 \pm 79.6$ & 0.70 \\
\hline $\begin{array}{l}\text { TORORO } \\
\text { ROCK }\end{array}$ & $1116.8 \pm 35.5$ & 1.37 \\
\hline $\begin{array}{l}\text { BUBENZI } \\
\text { QUARRIES }\end{array}$ & $242.2 \pm 19.7$ & 0.30 \\
\hline $\begin{array}{l}\text { NKOTA } \\
\text { QUARRIES }\end{array}$ & $794.8 \pm 68.4$ & 1.00 \\
\hline $\begin{array}{l}\text { NATONDOME } \\
\text { QUARRIES }\end{array}$ & $879.8 \pm 60.5$ & 1.10 \\
\hline
\end{tabular}

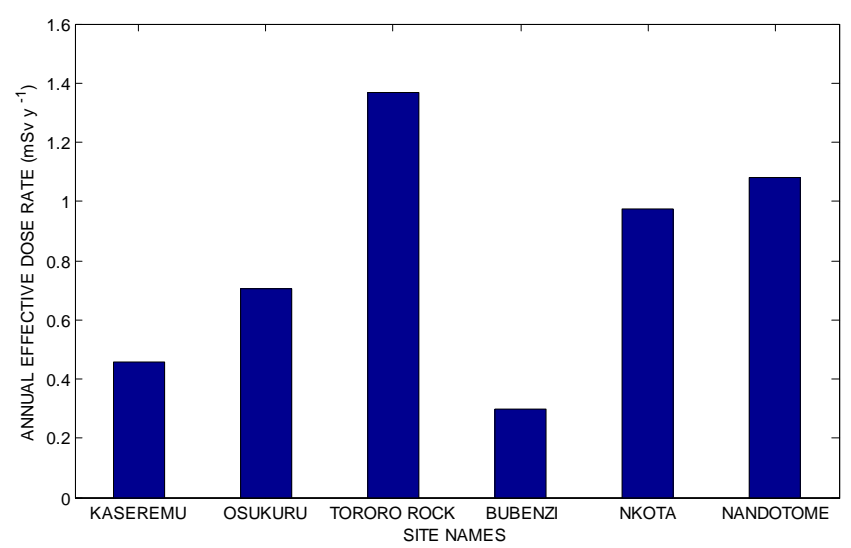

Figure 4: The annual effective dose rate outdoor for the sites under study

Figure 4, shows that Tororo rock has the highest annual effective dose rate followed by Nandotome quarries while Bubenzi quarries has the least. The International commission on radiological protection recommended the annual effective dose rate permissible limit for public exposure as $1 \mathrm{mSv} \mathrm{y}^{-1}$ [11]. From the results of this work, Kaseremu mines and Bubenzi quarries have annual effective dose rate below the permissible limit for public exposure. This means that these sites are safe for human activities and the rocks from these sites are safe to be used as building materials. But great precaution has to be taken because radiation at any level poses a health risk.

Tororo rock mines, Nkota quarries and Nandotome quarries have annual effective dose rates greater than the annual effective dose rate permissible limit for public exposure [11]. They can be regarded as high background radiation areas and measures should be taken to safe guard the public. Building materials from these sites may not be safe for use and the rocks from these sites should not be used for construction of houses. 


\section{CONCLUSION}

The study revealed that average specific activities of ${ }^{238} \mathrm{U}$, ${ }^{232} \mathrm{Th}$ and ${ }^{40} \mathrm{~K}$ for all sites studied were much above the world average. The trend of specific activities of the radionuclides studied were in the order of magnitude ${ }^{40} \mathrm{~K}>{ }^{232} \mathrm{Th}>{ }^{238} \mathrm{U}$ in all the sites studied apart from Tororo rock and Osukuru hills where the specific activities were in the order ${ }^{232} \mathrm{Th}>{ }^{40} \mathrm{~K}>{ }^{238} \mathrm{U}$.

The calculated average absorbed dose rates in air at all the sites were higher than the world average $\left(59 \mathrm{nGy} \mathrm{h}^{-1}\right)$. Thorium and potassium contributed the highest and lowest values respectively to the mean absorbed dose rates in the quarries.

The average annual effective dose measured for Tororo rock, Nkota quarry and Nandotome quarry is greater than unity, the annual effective dose rate permissible limit for public exposure recommended by ICRP [11]. This shows that the radiation hazard from terrestrial naturally occurring radionuclides at Tororo rock, Nandotome and Nkota in Sironko is great and significant. Therefore rocks in these areas are not safe for construction of houses and should not be used as building materials. Furthermore, these areas may not be safe for residential purposes especially Tororo rock, which has the highest Annual effective dose rate of 1.37 $\mathrm{mSv} \mathrm{y}^{-1}$.

\section{ACKNOWLEDGEMENT}

We appreciate the management of Radioisotope laboratory Makerere University for allowing us use their equipment to carry out the measurements done in this work. Particularly, we thank Mr Kwizera the laboratory technician for the technical support he accorded us while conducting this study. May God bless them abundantly.

\section{REFERENCES}

[1] Achola S.O. (2009). Radioactivity and elemental analysis of carbonites rocks from parts of Gwasi area, south western Kenya. M.Sc. Thesis, University of Nairobi.

[2] Arafa W. (2004). Specific activity and hazards of granite samples collected from the eastern desert of Egypt. J. Environ. Radioactivity, 75: 315-327.

[3] Banzi, F.P., Kifanga, L. D. and Bundala, F. M. (2000). Natural radioactivity and radiation exposure at the Minjingu Phosphate mine in Tanzania, J. Radiol. Prot. 20: 41-51.

[4] Cember H and Thomas E. J. (2009). Introduction to Health Physics. Fourth edition. Department of Environment and Radiological Health sciences Colorado State University. Fort Collins Colorado.

[5] Faure G. (1986). Principles of Isotope Geology, $2^{\text {nd }}$ ed. Xv +589pp. New York, Chichester, Brisbane, Toronto, Singapore: John Willey and Sons: ISBN (10): 0471864129.

[6] Frisch O. R. (1958). The nuclear handbook. George Newnest limited London. Great Britain.
[7] Gilmore G and Hemingway J.(1995). Practical Gamma-Ray Spectrometry. John Wiley \& Sons, Chichester.

[8] Harb S., El-Kamel A., Abd El-Mageed A., Abbady A. and Negm H. (2008). Natural Radioactivity Measurements in Soil and Phosphate Samples from ElSabaea, Aswan, Egypt, Rad. Phy. \& Prot. Conf., 15-19 Nov. 233-237 pp, Nasr City - Cairo, Egypt.

[9] International Atomic Energy Agency (IAEA). (2004). Soil sampling for environmentalcontaminants. IAEATECDOC-1415, Vinna.

[10] International Commission on Radiological Protection (ICRP). ( 2002). Guide for the Practical Application of the ICRP Human Respiratory Tract Model. Supporting Guidance 3. ICRP Publication 90. Ann ICRP, 32(1-2). Elsevier Science Ltd, Oxford,.

[11] International Commission on Radiological Protection (ICRP). (2000). Protection of the public in situations of prolonged radiation exposure; ICRP Publication 82; Pergamon Press, Oxford. Ann. ICRP, 29(1-2).

[12] Kinyua R1, Atambo VO, Ongeri R.M. (2011). Activity concentration of ${ }^{40} \mathrm{~K},{ }^{232} \mathrm{Th},{ }^{226} \mathrm{Ra}$ and Radiation exposure levels in the Tabaka soap stone Quarries of Kisii Region, Kenya. Afr. J.Env.Sci. Tech, 5(9):682688.

[13]Lameriga Y. (1998). Low level radionuclide counting of $\mathrm{Cs}, \mathrm{U}, \mathrm{Th}$ and $\mathrm{K}$ in selected Ugandan foods and their corresponding soils of growth: Thesis submitted to Makerere University.

[14]Langat K. W. (2012). Gamma ray spectrometric analysis of sediment deposits at the shores of lake Nakuru, Kenya; Thesis submitted to Kenyatta University.

[15] Michalis, T., and Haralabos, T. (2002). Gamma ray measurements of naturally occurring radioactive samples from Cyprus characteristic geological rocks. Department of Physics, University of Cyprus, Nicosia, Cyprus, UCY-PHY-02/02.

[16] Myrick, T.E., Berven, B.A. and Haywood, F.F. (1983). Determination of the concentration of selected radionuclides in surface soil in USA. Health Phys.

[17] Orgun, Y., Altinsoy, N., Sahin, S.Y., Gungor, Y., Gultekin, A.H., Karaham, G., Karaak, Z. (2007). Applied Radiation and Isotopes, 65, 739-747.

[18]Ramasamy, V., Senthil S., Meenakshisundaram, V. and Gajendran, V. (2009). Measurement of natural radioactivity in beach sediments from north east coast of Tamilnadu, India, Res. J. Appl. Sc. Engin. Tech. 1 (2): $54-58$

[19] Shaw P. (2007). Natural Radiation \& NORM: Defining the challenge, in the $3^{\text {rd }}$ International Conference on Natural Radiation \& NORM, IBC Global Conferences: London.

[20]UNSCEAR. (1993). Sources and Effects of Ionizing Radiation. Report to General Assembly, with Scientific Annexes, United Nations, New York.

[21] UNSCEAR. (2000). United Nations Scientific Committee on the Effect of Atomic Radiation. Sources and Effects of Ionizing Radiation. Report to General 
Assembly, with Scientific Annexes, United Nations, New York.

[22]UNSCEAR. (2008). Sources and Effects of Ionizing Radiation. Report to General Assembly, VOLUME II with Scientific Annexes, C, D and E.

[23] WHO. Ionizing radiation, health effects and protective measures, Fact sheet N ${ }^{\circ} 371$ November 2012.

[24]Wicker F.W. and Schults V. (1982). Journal on Radioecology, Nuclear Energy the Environment Volumes 1 and 2.

[25]William L.K. (2012). Gamma ray spectrometric analysis of sediment deposits at the shores of lake Nakuru, Kenya; Thesis submitted to Kenyatta University. 